\title{
PENGARUH IMPLEMENTASI SAK ETAP DAN SOP KEUANGAN TERHADAP MUTU LAPORAN KEUANGAN USAHA KECIL MENENGAH BINAAN DINAS KOPERASI DAN USAHA MIKRO KECIL MENENGAH DI KOTA DEPOK
}

\author{
Karsimin \\ Sekolah Tinggi Ilm Ekonomi (STIE) Manajemem Bisnis Indonesia, Jakarta, Indonesia \\ Jakartakarsimin.gk65@gmail.com
}

Received: 30-01-2021

Revised: 19-02-2021

Accepted: 24-02-2021

\section{Abstract}

This study aims to produce information in the form of a more in-depth explanation of the effect of implementation of SAK ETAP and Financial SOP on the quality of financial reports. And get the results from data processing on how much influence the implementation of SAK ETAP and Financial $S O P$ on the quality of financial reports. The research method used in this study, the data obtained, both quantitative and qualitative, were researched using descriptive methods, namely in the form of field studies and direct surveys either through interviews or observations in the form of direct observation. Based on calculations with the simple linear regression equation between $X$ and $Y$ is $\hat{Y}=21.581+$ $0.217 X 1+0.269 X 2+\ldots \ldots e$, this means that if there is an increase in the implementation of SAK ETAP and Financial SOPs by 1 point, the quality of the financial statements will experience an increase to be $21.581+0.217+0.269(1)=$ 22.067. While the results of the Hypothesis Testing, it was found that the SAK ETAP implementation variable obtained tcount $1.669<$ ttable 2.01669 and a significance 0.103>0.05, so it can be said that the independent variables are proven to be not related to the quality of financial reports. Financial SOP with tcount $=2.061>$ ttable 2.01669 and a significance of $0.045<0.05$, it can be said that the Financial SOP variable is proven to have a relationship between Financial SOPs and the Quality of Financial Statements. And based on the correlation coefficient analysis, the value of $R=0.444$ means that the relationship is moderate between the implementation of SAK ETAP (XI) and the Quality of Financial Statements $(Y)$. The relationship between the Financial SOP $(X 2)$ and the Quality of Financial Statements $(Y)$ of $R=0.472$ has a moderate relationship between the Financial SOP variable and the Quality Financial Statement variable. While the result of $K D(R \wedge 2)=23.6 \%$. This means that $23.6 \%$ of the independent variables, namely the implementation of SAK ETAP and Financial SOPs, can explain the dependent variable, namely the Quality of Financial Statements. While the remaining $76.4 \%$ is explained by other factors not examined by this study. The results of the $F$ test obtained Fcount > Ftable, namely 7.814> 4.07, then the Ha hypothesis is accepted, that SAK ETAP and Financial SOPs have an 
effect on the quality of SME financial reports.

Keywords: SAK ETAP; financial SOP; quality offFinancial statements.

\section{Abstrak}

Penelitian ini bertujuan untuk menghasilkan informasi berupa penjelasan yang lebih mendalam tentang pengaruh implementasi SAK ETAP dan SOP Keuangan terhadap mutu laporan keuangan dan memperoleh hasil dari olahan data tentang seberapa besar pengaruh implementasi SAK ETAP dan SOP Keuangan terhadap mutu laporan keuangan. Metode penelitian yang digunakan kuantitatif maupun yang bersifat kualitatif diteliti dengan menggunakan metode deskriptif, yakni dengan bentuk kajian lapangan dan survey langsung baik melalui wawancara maupun observasi berupa pengamatan langsung. Berdasarkan perhitungan dengan persamaan regresi linier sederhana antara $\mathrm{X}$ dan $\mathrm{Y}$ adalah $\hat{\mathrm{Y}}=21,581+0,217 \mathrm{X}_{1}+0,269 \mathrm{X}_{2}$ +.....e, ini berarti apabila ada peningkatan implementasi SAK ETAP dan SOP Keuangan sebesar 1 poin maka mutu laporan keuangan akan mengalami peningkatan menjadi sebesar $21,581+0,217+0,269(1)=22,067$. Sedangkan hasil dari Pengujian Hipotesis, diperoleh variabel implementasi SAK ETAP diperoleh $t_{\text {hitung }} 1,669<t_{\text {tabel }}$ 2,01669 dan signifikansi 0,103>0,05 maka dapat dikatakan bahwa variabel bebas terbukti tidak berhubungan dengan mutu laporan keuangan. SOP Keuangan dengan $t_{\text {hitung }}=$ $2,061>t_{\text {tabel }} 2,01669$ dan signifikansi $0,045<0,05$ maka dapat dikatakan bahwa variabel SOP Keuangan terbukti terdapat hubungan antara SOP Keuangan dengan Mutu Laporan Keuangan. Berdasarkan analisa koefisien korelasi diperoleh nilai $\mathrm{R}=0,444$ artinya hubungannya sedang antara Implementasi SAK ETAP (X1) dengan Mutu Laporan Keuangan (Y). Hubungan antara SOP Keuangan (X2) dengan Mutu Laporan Keuangan ( $\mathrm{Y}$ ) sebesar $\mathrm{R}=0,472$ mempunyai hubungan sedang antara variabel SOP Keuangan dengan variabel Mutu Laporan Keuangan. Sedangkan hasil KD $\left(R^{2}\right)=23,6 \%$. Artinya $23,6 \%$ variabel independen yaitu implementasi SAK ETAP dan SOP Keuangan dapat menjelaskan variabel dependen yaitu Mutu Laporan Keuangan. Sedangkan sisanya 76,4\% dijelaskan oleh faktor lain yang tidak diteliti oleh penelitian ini. Hasil uji $\mathrm{F}$ diperoleh $\mathrm{F}_{\text {hitung }}>\mathrm{F}_{\text {tabel }}$ yaitu 7,814> 4,07 maka hipotesis Ha diterima, bahwa SAK ETAP dan SOP Keuangan berpengaruh terhadap mutu laporan keuangan UKM.

Kata Kunci : SAK ETAP; SOP keuangan; mutu laporan keuangan. 


\section{PENDAHULUAN}

Menurut Undang-undang Nomor 20 Tahun 2008 tentang Usaha Mikro, Kecil dan Menengah (UMKM) merupakan usaha produktif milik orang perorangan atau badan usaha perorangan yang memenuhi kriteria UKM. UKM sangat mempunyai peranan penting dalam pertumbuhan perekonomian warga . UKM pula sangat membantu negara atau pemerintah dalam hal penciptaan lapangan kerja, pemerataan pendapatan dan pengentasan kemiskinan (Pujiyanti, 2018).

Tujuan Pemberdayaan UKM Undang-undang Pasal 5 ayat (1) yaitu mewujudkan struktur perekonomian nasional yang seimbang, berkembang dan berkeadilan. Pemanfaatan UKM terbukti mampu memaksimalkan potensi sumber daya yang ada, karena UKM biasanya bergerak dalam sektor industri lokal dan tidak bergantung pada impor, dengan hasil yang beragam dan unik sehingga mampu bersaing di pasar ekspor. Perekonomian Indonesia dapat menunjukkan kemampuannya dalam memiliki fundamental yang kuat, apabila koperasi dan UKM dapat menjadi pelaku utama dalam perekonomian nasional yang produktif serta memiliki daya saing (Alhusain, 2016).

Data dari Kementrian KUKM Indonesia pada Tuti \& Dwijayanti (2016) menyatakan bahwa UMKM mampu memberikan kontribusi sebesar 56\% untuk Pendapatan Domestik Bruto (PDB), dengan jumlah UKM yang mencapai 56,6 juta serta 99,8\% dari UMKM mampu menyerap 97\% tenaga kerja di Indonesia pada tahun 2013 (Tuti, 2016). Kontribusi UMKM yang besar terhadap perekonomian juga terjadi di banyak Negara, seperti yang dikutip dari Baas dan Schrooten (2006) menyatakan bahwa jumlah UKM di Negara maju mencapai $90 \%$ dari keseluruhan usaha serta mampu menyerap tenaga kerja 2/3 dari jumlah pengangguran yang terdapat di negara-negara tersebut (Baas \& Schrooten, 2006).

Kelebihan lain asal UKM merupakan pada membuat produk-produk baru yang inovatif dan kreatif, sehingga menghasilkan produk-produk yang lebih berguna dan bisa dinikmati oleh rakyat secara luas. Selain itu, kiprah strategis asal UKM sebagai cara lain pengamanan warga terhadap ancaman krisis serta turbulensi ekonomi (Ardhanariswari, Wijayani, \& Probosari, 2021). Dibuktikan dengan keberhasilan sektor usaha kecil dan menengah dalam bertahan serta mendinamiskan kondisi perekonomian Indonesia pada saat krisis ekonomi 1997.

Potensi yang besar asal UKM tersebut sering terkendala persoalan permodalan buat mengembangkan perjuangan. Sebenarnya ada acara pembiayaan UKM yg dijalankan oleh pemerintah. salah satu acara tadi adalah Kredit usaha masyarakat (KUR) yang pada tahun 2009 ditargetkan kurang lebih Rp. 20 triliun. Tujuan dari KUR tersebut adalah buat sebagai solusi pembiayaan modal yang efektif bagi UKM, sebab selama ini banyak UKM yang terkendala akses terhadap perbankan buat mendapatkan pembiayaaan (Osa 2010). tetapi realisasi KUR tersebut jauh berasal target Rp 20 triliun yakni hanya sebanyak Rp 14,8 triliun.

Dengan akuntansi yang memadai maka pengusaha UKM dapat memenuhi persyaratan dalam pengajuan kredit, seperti pembuatan laporan keuangan (Utami, 2014). Namun pelaksanaan pembukuan tersebut merupakan hal yang sulit bagi UKM karena keterbatasan pengetahuan mengenai akuntansi, rumitnya proses akuntansi, dan anggapan bahwa laporan keuangan bukanlah hal yang penting bagi UKM (Said, 2015). Berbagai macam keterbatasan lain yang dihadapi UKM adalah latar belakang pendidikan yang 
tidak paham akuntansi atau tata kitab , kurang disiplin pada melaksanakan pembukuan akuntansi, dan tidak adanya dana yang cukup buat mempekerjakan akuntan atau membeli aplikasi akuntansi buat mempermudah aplikasi pembukuan akuntansi.

Dewan Standar Akuntansi Keuangan (DSAK) pada tahun 2009 telah mensahkan Standar Akuntansi untuk Entitas Tanpa Akuntabilitas Publik (SAK ETAP). SAK ETAP tersebut akan berlaku efektif per 1 Januari 2011 namun penerapan sebelum tanggal efektif diperbolehkan. Penggunaan SAK ETAP ini adalah ditujukan untuk entitas tanpa akuntabilitas publik yakni entitas yang : 1). Tidak memiliki akuntabilitas publik yang signifikan, dan 2). Entitas yang menerbitkan laporan keuangan untuk tujuan umum bagi pengguna eksternal. SAK ETAP merupakan standar akuntansi yang penggunaannya ditujukan untuk entitas usaha yang tidak memiliki akuntabilitas publik, seperti entitas usaha mikro kecil, dan menengah (UMKM). SAK ETAP ini lebih mudah dipahami dan tidak sekompleks SAK Umum. Selain adanya SAK ETAP tersebut, kemudahan lain bagi UKM dalam hal pembukuan akuntansi adalah semakin banyaknya software akuntansi yang dapat digunakan UKM. Ke depannya diharapkan UKM mampu melakukan pembukuan akuntansi untuk menyajikan laporan keuangan sehingga lebih mudah bagi para pengusaha UKM untuk memperoleh pembiayaan.

Standar Operasional prosedur (SOP) merupakan serangkaian instruksi tertulis yang terdokumentasi mengenai aneka macam proses penyelenggaraan administrasi, bagaimana serta kapan wajib dilakukan, dimana serta oleh siapa dilakukan. SOP ini sangat diharapkan menjadi standar akuntansi buat memberi panduan serta peraturan bagi akuntan publik agar dapat melaksanakan tugas dengan independen, hati-hati, dan bisa menggunakan keahliannya dengan kejujuran pada penyusunan laporan keuangan.

Laporan keuangan ialah suatu informasi yang mendeskripsikan kondisi keuangan usaha, pengambilan keputusan yg akurat serta tepat ketika serta pertanggung jawaban di manajemen serta yg diperoleh berasal akibat perjuangan. Laporan keuangan sangat berguna untuk menilai kinerja usaha dan bisa membantu pada menghadapi pertarungan dalam menjalankan perjuangan khususnya UKM.

Pemerintah Kota (Pemkot) Depok memiliki komitmen untuk mendongkrak jumlah para pelaku Usaha Kecil dan Menengah (UKM). Keberadaan para pengusaha tersebut dinilai berperan penting dalam memajukan perekonomian Kota Depok (Andi Nur Aminah, 2019). Saat ini jumlah pelaku UMKM Depok sekitar 2.385 orang memiliki kontribusi yang besar dalam membangun Kota Depok, seperti mengurangi angka pengangguran. Kepala Dinas Koperasi dan Usaha Mikro (DKUM) Kota Depok, Mohammad Fitriawan sepakat keberadaan UMKM Kota Depok dapat menurunkan angka pengangguran. Sebab, pelaku UMKM ada yang melibatkan asisten rumah tangga, tetangga, atau saudara untuk mengembangkan usaha mereka.

Anggraeni, Hardjanto dan Hayat (2013) menambahkan bahwa permasalahan yang paling fundamental dihadapi oleh pelaku UKM ini mencakup, sumber daya insan yang kurang mempunyai ilmu pengetahuan serta keterampilan dalam pengembangan usahanya, memiliki permasalahan pada permodalan, kurangnya sarana dan prasarana serta kurangnya akses pemasaran produk (Anggraeni, 2013).

Untuk masalah permodalan itu sendiri, pemerintah lewat LPDB (Lembaga Pengelola Dana Bergulir) membagikan dana tersebut lewat koperasi bagi para pengusaha UKM yang akan melakukan pinjaman modal. Untuk menyelesaikan permasalahan tersebut, maka koperasi merupakan kelembagaan yang dapat memberdayakan UKM.

Namun, jika melihat dari permasalahan-permasalahan tersebut dan jika dibiarkan, tentu akan banyak koperasi tidak dapat berkembang dengan baik. Maka diperlukan kolaborasi antara koperasi, pihak eksternal seperti pemerintahan dan BUMD (Badan Usaha Milik Daerah) agar bisa membantu berkonstribusi pada pendapatan daerah dan memaksimalkan peran BUMD untuk kepentingan daerah itu sendiri dan menerapkan 
akan pemahaman pentingnya akuntansi dan SOP keuangan dalam usaha dengan memberikan evaluasi dan sosialisasi tentang implementasi SAK ETAP dan SOP keuangan terhadap mutu laporan keuangan.

Namun penelitian terdahulu yang telah dilakukan oleh Fatimah dan Darna (2011) menunjukan bahwa begitu banyaknya koperasi yang menutup kegiatan usahanya adalah merupakan tantangan berat yang dihadapi oleh pemerintah dan dinas koperasi sendiri di Kota Depok (Fatimah \& Darna, 2011). Pada tahun 2010, dari sebanyak 880 unit koperasi ternyata hanya 290 unit koperasi yang masih aktif.

\section{METODE PENELITIAN}

Penelitian ini menggunakan metode pengaruh dan jenis deskriptif verifikatif, yaitu dengan cara mengumpulkan dan menafsirkan data yang ada sehingga memberikan gambaran yang jelas mengenai analisis data sehingga dapat diketahui gambaran umum objek yang diteliti (Sugiyono, 2011). Tujuan dari metode dan jenis deskriptif ini yaitu membuat suatu uraian yang sistematis mengenai fakta-fakta dan sifat-sifat dari objek yang diteliti kemudian menggabungkan hubungan antar variabel yang terlibat didalamnya. Metode deskriptif digunakan untuk menggambarkan implementasi SAK ETAP dan SOP keuangan terhadap mutu laporan keuangan usaha kecil menengah binaan DKUM di kota Depok.

Sedangkan jenis penelitian verifikatif menurut Hasan (2013:11) adalah penelitian yang menguji kebeneran sesuatu (pengetahuan) dalam bidang yang telah ada dan digunakan untuk menguji hipotesis yang menggunakan perhitungan statistik (Hasan, 2013). Bentuk penelitian ini kualitatif dan kuantitatif, digunakan untuk menguji kebenaran hipotesis yaitu SAK ETAP dan SOP keuangan terhadap mutu laporan keuangan.

Bentuk penelitian kualitatif merupakan suatu metode yang sifatnya berupa pemahaman dan materi yang mengguakan kata - kata untuk mencari data. Sehingga, data yang diperoleh dari hasil penelitian kualitatif tidak bisa diukur dengan angka. Biasanya data ini dapat berupa motivasi masyarakat, alasan atau lainnya.

\section{HASIL DAN PEMBAHASAN}

\section{Deskripsi Data Penelitian}

Deskripsi data yang disajikan dari hasil penelitian ini adalah untuk memberikan gambaran secara umum mengenai penyebaran data yang diperoleh dilapangan dengan menggunakan kuesioner. Berikut resume persepsi responden yang diperoleh berdasarkan data primer yang didapat. 
Tabel 1.

Resume Persepsi Responden

\begin{tabular}{|r|l|r|r|r|r|r|r|}
\hline \multirow{2}{*}{ No } & \multirow{2}{*}{ No Pernyataan } & \multicolumn{2}{|c|}{ Implementasi SAK ETAP } & \multicolumn{2}{c|}{ SOP Keuangan } & \multicolumn{2}{c|}{ Mutu Laporan Keuangan } \\
\cline { 3 - 8 } & & \multicolumn{2}{|c|}{ Variabel (X1) } & \multicolumn{2}{|c|}{ Variabel (X2) } & \multicolumn{2}{c|}{ Variabel (Y) } \\
\cline { 2 - 8 } & & Jumlah & Rata-Rata & Jumlah & Rata-Rata & Jumlah & Rata-Rata \\
\hline 2 & Pernyataan 1 & 171 & 3.8 & 194 & 4.31 & 196 & 4.36 \\
\hline 3 & Pernyataan 3 & 166 & 3.69 & 187 & 4.16 & 189 & 4.2 \\
\hline 4 & Pernyataan 4 & 199 & 4.42 & 195 & 4.33 & 192 & 4.27 \\
\hline 5 & Pernyataan 5 & 182 & 4.18 & 188 & 4.18 & 190 & 4.22 \\
\hline 6 & Pernyataan 6 & 182 & 4.04 & 195 & 4.33 & 192 & 4.27 \\
\hline 7 & Pernyataan 7 & 183 & 4.04 & 193 & 4.29 & 189 & 4.2 \\
\hline 8 & Pernyataan 8 & 182 & 4.04 & 192 & 4.27 & 191 & 4.24 \\
\hline 9 & Pernyataan 9 & 179 & 3.98 & 191 & 4.22 & 189 & 4.24 \\
\hline 10 & Pernyataan 10 & 176 & 3.91 & 191 & 4.24 & 193 & 4.29 \\
\hline & Jumlah & 1808 & 40.17 & 1916 & 42.57 & 1916 & 4.33 \\
\hline & Min & 166 & 3.69 & 187 & 4.16 & 189 & 42.58 \\
\hline & Max & 199 & 4.42 & 195 & 4.33 & 196 & 4.2 \\
\hline & Rata-rata & 180.8 & 4.017 & 191.6 & 4.257 & 191.6 & 4.258 \\
\hline
\end{tabular}

Sumber : Diolah, 2020

Dari Tabel 1 dapat dilihat jumlah dan rata-rata persepsi responden dari setiap pernyataan yang diajukan dalam peneliltian. Berdasarkan jumlah jawaban dari 10 pernyataan yang membahas Implementasi SAK ETAP (variabel X1), jumlah terkecil pada variabel tersebut terdapat pada pernyataan nomor 2 (dua) dengan jumlah 166. Dan jumlah nilai terbesar pada variabel X1 adalah 199 terdapat pada butir pernyataan nomor 3 (tiga). Untuk jumlah jawaban dari 10 pernyataan yang membahas SOP Keuangan (variabel X2), jumlah nilai terkecil terdapat pada nomor 2 (dua) dengan jumlah 187, sementara nilai terbesar terdapat pada pernyataan nomor 5 (lima) dengan jumlah 195. Untuk jumlah jawaban dari 10 pernyataan yang membahas Mutu Laporan Keuangan (variabel Y), jumlah nilai terkecil terdapat pada nomor 2 (dua) dengan jumlah 189, sementara nilai terbesar terdapat pada pernyataan nomor 1 (satu) dengan jumlah 196.

Resume persepsi responden merupakan ringkasan data primer yang diperoleh dari jawaban responden mengenai pernyataan variabel melalui penyebaran kuesioner. Data primer yang diperoleh selanjutnya diolah menggunakan perangkat lunak komputer Statistical Product and Services Solutions (SPSS) versi 26.0 untuk dianalisis. Olahan data tersebut akan dianalisis lebih lanjut melalui beberapa proses pengujian guna mendapatkan hasil penelitian. Olahan data dari jawaban setiap item pernyataan tersebut dapat menampilkan distribusi frekuensi jawaban yang merupakan persepsi responden atas setiap variabel yang diteliti.

Untuk itu diambil jumlah populasi nya 82 pelaku UKM. Untuk mendapatkan jumlah pengambilan sampel dengan standar toleransi kesalahan sebesar 10\% maka dapat dihitung memakai rumus slovin yaitu :

$$
\begin{aligned}
& \mathrm{n}=\frac{\mathrm{N}}{\mathrm{N} \cdot \mathrm{d}^{2}+1} \\
& \mathrm{n}=\frac{82}{82(0,1)^{2}+1}
\end{aligned}
$$




$$
\begin{aligned}
& \mathrm{n}=\frac{82}{82(0,01)+1} \\
& \mathrm{n}=\frac{82}{0,82+1} \\
& \mathrm{n}=\frac{82}{1,82} \\
& \mathrm{n}=45,0549
\end{aligned}
$$

Berdasarkan hasil perhitungan yang didapatkan dari rumus slovin, maka diketahui jumlah sampelnya adalah sebanyak 45 pelaku pada UKM.

\section{Frekuensi Identitas Responden}

Responden dalam penelitian ini adalah 45 pelaku usaha pada Usaha Kecil Menengah di kota depok. Profil identitas responden pada penelitian dapat dijelaskan sebagai berikut.

a. Profil Responden Berdasarkan Jenis Kelamin

Berikut data jumlah responden laki-laki dan perempuan yang diperoleh dari hasil penyebaran kuesioner.

Tabel 2.

Jenis Kelamin

\begin{tabular}{llllll}
\hline & & Frequency & Percent & $\begin{array}{l}\text { Valid } \\
\text { Percent }\end{array}$ & $\begin{array}{l}\text { Cumulative } \\
\text { Percent }\end{array}$ \\
\hline Valid & Laki - Laki & 21 & 46,7 & 46,7 & 46,7 \\
\cline { 2 - 6 } & Perempuan & 24 & 53,3 & 53,3 & 100,0 \\
\cline { 2 - 5 } & Total & 45 & 100,0 & 100,0 & \\
\hline
\end{tabular}

Sumber : Hasil Pengolahan SPSS versi 26

Dari tabel 2 profil responden berdasarkan jenis kelamin ditampilkan secara rinci pada tabel tersebut yaitu 21 orang atau $46,7 \%$ berjenis kelamin laki-laki dan 24 orang atau 53,3\% berjenis kelamin perempuan.

b. Profil Responden Berdasarkan Pendidikan Terakhir

Berikut data profil responden berdasarkan pendidikan terakhir yang diperoleh dari penyebaran kuesioner dan telah dibagi menjadi 4 kelompok.

Tabel 3.

Pendidikan Terakhir

\begin{tabular}{llllll}
\hline & & Frequency & Percent & $\begin{array}{l}\text { Valid } \\
\text { Percent }\end{array}$ & $\begin{array}{l}\text { Cumulative } \\
\text { Percent }\end{array}$ \\
\hline Valid & SMP & 1 & 2,2 & 2,2 & 2,2 \\
\cline { 2 - 6 } & SMA & 22 & 48,9 & 48,9 & 51,1 \\
\cline { 2 - 6 } & S1 & 22 & 48,9 & 48,9 & 100,0 \\
\cline { 2 - 6 } & Total & 45 & 100,0 & 100,0 & \\
\hline
\end{tabular}

Sumber : Hasil Pengolahan SPSS versi 26

Pada Tabel 3 profil responden berdasarkan pendidikan terakhir secara rinci dapat dijelaskan bahwa sejumlah 1 orang atau 2,2\% responden adalah dari pendidikan SMP, 22 orang atau 48,9\% responden adalah dari pendidikan SMA, dan dapat 
dijelaskan juga bahwa sejumlah 22 orang atau $48,9 \%$ responden adalah dari pendidikan S1.

c. Profil Responden Berdasarkan Bidang Usaha

Berikut data profil responden berdasarkan bidang usaha yang diperoleh dari penyebaran kuesioner dan telah dibagi menjadi 5 kelompok.

Tabel 4.

\section{Bidang Usaha}

\begin{tabular}{llllll}
\hline & Frequency & Percent & $\begin{array}{l}\text { Valid } \\
\text { Percent }\end{array}$ & $\begin{array}{l}\text { Cumulative } \\
\text { Percent }\end{array}$ \\
\hline Valid & Kuliner & 23 & 51,1 & 51,1 & 51,1 \\
\cline { 2 - 6 } & Fashion & 8 & 17,8 & 17,8 & 68,9 \\
\cline { 2 - 6 } & Pendidikan & 2 & 4,4 & 4,4 & 73,3 \\
\cline { 2 - 6 } & Otomotif & 3 & 6,7 & 6,7 & 80,0 \\
\cline { 2 - 6 } & Lain-Lain & 9 & 20,0 & 20,0 & 100,0 \\
\cline { 2 - 6 } & Total & 45 & 100,0 & 100,0 & \\
\hline
\end{tabular}

Sumber : Hasil Pengolahan SPSS versi 26

Pada Tabel 4 profil responden berdasarkan bidang usaha secara rinci dapat dijelaskan bahwa sejumlah 23 orang atau $51,1 \%$ responden adalah dari bidang kuliner, 8 orang atau 17,8\% responden adalah dari bidang fashion, 2 orang atau 4,4\% responden adalah dari bidang pendidikan, 3 orang atau $6,7 \%$ responden adalah dari bidang otomotif dan dapat dijelaskan juga bahwa sejumlah 9 orang atau $20,0 \%$ responden berasal dari bidang photography, sablon, agrobisnis dan lainnya.

\section{A. Hasil Olahan}

Dari hasil olahan data menggunakan perangkat lunak komputer Statistical Product and Services Solutions (SPSS) versi 26.0. menghasilkan uraian dari beberapa pengujuian data yang dilakukan. Diantaranya seperti uji normalitas, uji multikolinearitas, uji heteroskedastisitas, uji otokolerasi, uji analisis koefisien kolerasi, analisis koefisien determinasi, analisis regresi linier berganda, uji t (uji hubungan), uji F (uji simultan).

\section{a. Uji Data (Uji Normalitas)}

Pengolahan data yang selanjutnya dilakukan adalah uji normalitas. Uji normalitas bertujuan untuk menguji apakah dalam model regresi, variabel residu memiliki distribusi normal atau tidak. Dalam penelitian ini, uji normalitas menggunakan uji One Sample Kolmogorov Smirnov. Pengujian normalitas data untuk variabel-variabel yang diteliti memiliki dasar pengambilan keputusan, yaitu dengan membandingkan besarnya nilai Asymp Sig (2-tailed) hitung yang diperoleh dengan besarnya $\mathrm{Sig}=0,05$ dengan kriteria:

a. Jika nilai Sig $>0,05$ maka data berdistribusi normal.

b. Jika nila Sig < 0,05 maka data berdistribusi tidak normal. 
Berikut hasil dari uji normalitas Kolmogorov-Sirnov :

Tabel 5.

Hasil Uji Normalitas

One-Sample Kolmogorov-Smirnov Test

\begin{tabular}{llr}
\hline & & \multicolumn{1}{c}{ Unstandardized Residual } \\
\hline $\mathrm{N}$ & & 45 \\
\hline Normal Parameters & & \\
& Mean & 0,0000000 \\
\cline { 2 - 3 } & Std. Deviation & 3,58127804 \\
\hline Most Extreme Differences & Absolute & 0,088 \\
\cline { 2 - 3 } & Positive & 0,088 \\
\cline { 2 - 3 } & Negative & $-0,059$ \\
\hline Test Statistic & & 0,088 \\
\hline Asymp. Sig. (2-tailed) & &, $200^{\mathrm{c}, \mathrm{d}}$ \\
\hline
\end{tabular}

a. Test distribution is Normal

b. Calculated from data

c. Lilliefors Significance Correction

Sumber : Hasil Pengolahan SPSS versi 26

Dari hasil Uji Normalitas dengan metode Kolmogorov-Smirnov Test diperoleh hasil nilai Asymp.Sig (Signifikansi) sebesar 0,200>0,05 untuk variabel implementasi SAK ETAP dan SOP keuangan, dan nilai Asym.Sig (Signifikansi) sebesar 0,200 > 0,05 untuk variabel mutu laporan keuangan. Maka dari hasil uji normalitas data ketiga variabel penelitian dapat diartikan data berdistribusi normal.

\section{b. Uji Klasik}

a. Uji Multikolinieritas

Uji multikolinieritas bertujuan untuk menguji apakah model regresi ditemukan adanya kolerasi antar variabel bebas. Model regresi yang baik seharusnya tidak terjadi kolerasi di antara variabel independen. Jika variabel saling berkolerasi, maka variabel - variabel ini tidak ortogonal. Variabel ortogonal adalah variabel independen yang nilai kolerasi antar sesama variabel indenpenden sama dengan nol.

Salah satu cara mengetahui ada tidaknya multikolinieritas pada suatu model regresi adalah dengan melihat nilai tolerance dan VIF (Variabel Inflation Factor).

1. Jika nilai tolerance $>0,10$ dan $\mathrm{VIF}<10$, maka dapat diartikan bahwa tidak terdapat multikolinieritas pada penelitian tersebut.

2. Jika nilai tolerance $<0,10$ dan VIF $>10$, maka terjadi gangguan multikolinieritas pada penelitian tersebut.

Tabel 6.

Hasil Uji Multikolinearitas

\begin{tabular}{|c|c|c|c|c|c|c|}
\hline \multicolumn{7}{|c|}{ Coefficients $^{\mathrm{a}}$} \\
\hline \multirow[t]{2}{*}{ Model } & $\begin{array}{r}\text { Unsta } \\
\text { Coe }\end{array}$ & $\begin{array}{l}\text { dized } \\
\text { nts }\end{array}$ & $\begin{array}{l}\text { Standardized } \\
\text { Coefficients }\end{array}$ & $\mathbf{t}$ & Sig. & $\begin{array}{l}\text { Collinearity } \\
\text { Statistics }\end{array}$ \\
\hline & $\mathrm{B}$ & $\begin{array}{l}\text { Std. } \\
\text { Error }\end{array}$ & Beta & & & Tolerance \\
\hline
\end{tabular}




\begin{tabular}{|c|c|c|c|c|c|c|c|}
\hline (Constant) & 21,581 & 5,132 & & 4,205 & 0,000 & & \\
\hline $\begin{array}{l}\text { Implementasi } \\
\text { SAK ETAP }\end{array}$ & 0,217 & 0,130 & 0,264 & 1,669 & 0,103 & 0,694 & 1,442 \\
\hline $\begin{array}{c}\text { SOP } \\
\text { Keuangan }\end{array}$ & 0,269 & 0,130 & 0,326 & 2,061 & 0,045 & 0,694 & 1,442 \\
\hline
\end{tabular}

a. Dependent Variable: Mutu Laporan Keuangan

Sumber : Hasil Pengolahan SPSS versi 26

Berdasarkan Tabel 6 dapat diketahui bahwa nilai tolerance 0,694>0,10 dan VIF $1,442<10$, maka dapat diartikan tidak terdapat multikolinieritas pada penelitian tersebut.

b. Uji Heteroskedastisitas

Uji heteroskedastisitas bertujuan menguji apakah dalam model regresi terjadi ketidaksamaan varian dari residual satu pengamatan ke pengamatan yang lain. Jika varian dari residual satu pengamatan ke pengamatan lain tetap, maka disebut homoskedastisitas. Untuk mengetahui adanya heteroskedastisitas adalah dengan melihat ada atau tidaknya pola tertentu pada grafik ScatterPlot dengan ketentuan :

1. Jika terdapat pola tertentu, seperti titik-titik yang ada membentuk pola tertentu yang teratur maka menunjukkan telah terjadi heteroskedastisitas.

2. Jika tidak ada pola yang jelas, serta titik-titik menyebar diatas dan dibawah angka 0 pada sumbu Y, maka tidak terjadi heteroskedastisitas.

Tabel 7.

\section{Hasil Uji Heteroskedastisitas}

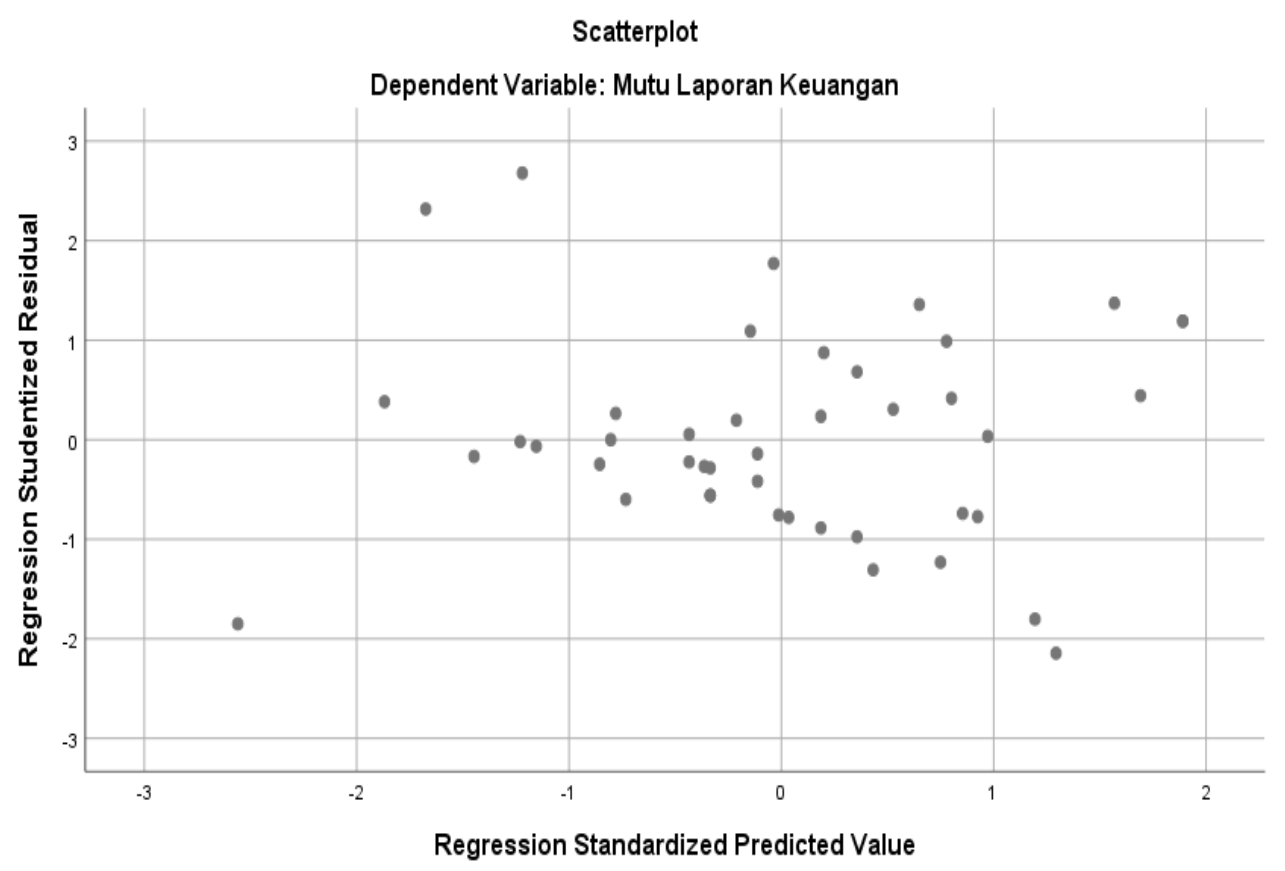

Sumber : Hasil Pengolahan SPSS versi 26

Berdasarkan Tabel 7 dapat diketahui bahwa hasil dari uji heteroskedastisitas menunjukan tidak ada pola yang jelas, serta titik-titik menyebar diatas dan dibawah angka 0 pada sumbu Y, maka dapat diartikan 
pengaruh implementasi SAK ETAP (X1) dan SOP Keuangan (X2) terhadap

\section{c. Uji Autokorelasi}

mutu laporan keuangan (Y) tidak terjadi heteroskedastisitas.

Uji autokolerasi ini bertujuan untuk mengetahui ada tidaknya autokolerasi, maka untuk mengetahui autokorelasi kita harus melihat nilai uji Durbin Watson. Metode pengujian yang sering digunakan adalah dengan uji Durbin Watson (uji DW) dengan ketentuan sebagai berikut :

1. Jika dw lebih kecil dari dL atau lebih besar dari (4- $\mathrm{dL}$ ) maka hipotesis nol ditolak, yang berarti terdapat otokolerasi.

2. Jika dw terletak antara dU dan (4- dL), maka hipotesis nol diterima, yang berarti tidak ada otokolerasi.

3. Jika dw terletak antara dL dan dU atau antara (4- dL) dan (4- dL), maka tidak menghasilkan kesimpulan yang pasti.

Tabel 8.

Hasil Uji Autokorelasi

\begin{tabular}{llllll}
\hline \multicolumn{4}{c}{ Model Summary $^{\mathrm{b}}$} \\
\hline Model & R & R Square & $\begin{array}{l}\text { Adjusted R } \\
\text { Square }\end{array}$ & $\begin{array}{l}\text { Std. Error of } \\
\text { the Estimate }\end{array}$ & $\begin{array}{l}\text { Durbin- } \\
\text { Watson }\end{array}$
\end{tabular}

\begin{tabular}{rrrrrr}
\hline 1 & $\mathbf{5 2 1}^{\mathrm{a}}$ & $\mathbf{0 , 2 7 1}$ & $\mathbf{0 , 2 3 6}$ & $\mathbf{3 , 6 6 6}$ & $\mathbf{2 , 3 2 2}$ \\
\hline
\end{tabular}

a. Predictors: (Constant), SOP Keuangan, Implementasi SAK ETAP

b. Dependent Variable: Mutu Laporan Keuangan

Sumber : Hasil Pengolahan SPSS versi 26

Dari hasil Tabel 8 nilai Durbin - Watson hitung sebesar 2,322. Dengan diperoleh Durbin - Watson tabel untuk $\mathrm{K}=2$ dan $\mathrm{N}=45$ adalah dari nilai dL ( batas bawah ) sebesar 1.4298 dan nilai dU ( batas atas ) sebesar 1.6148. Jadi berdasarkan pedoman - pedoman uji dU statistik Durbin - Watson dapat dilihat bahwa nilai DW 2,322 lebih besar daripada batas atas (du) 1,61 maka dapat diartikan tidak terdapat autokorelasi positif pada model regresi.

\section{B. Uji Metode}

a. Koefisien Korelasi

Uji Koefisien Korelasi ini digunakan untuk mengetahui kekuatan hubungan antara korelasi kedua variabel. Hubungan atau kekuatan hubungan dapat dilihat pada tabel model summary kolom R Tabel 9.

Tabel 9.

\section{Hasil Uji Koefisien Korelasi} Correlations

\begin{tabular}{|c|c|c|c|c|}
\hline & & $\begin{array}{c}\text { Mutu } \\
\text { Laporan } \\
\text { Keuangan }\end{array}$ & $\begin{array}{l}\text { Implementasi } \\
\text { SAK ETAP }\end{array}$ & $\begin{array}{c}\text { SOP } \\
\text { Keuangan }\end{array}$ \\
\hline $\begin{array}{l}\text { Mutu Laporan } \\
\text { Keuangan }\end{array}$ & $\begin{array}{l}\text { Pearson } \\
\text { Correlation }\end{array}$ & 1 &, $444^{* *}$ &, $472^{* * *}$ \\
\hline
\end{tabular}




\begin{tabular}{llrrr}
\hline & Sig. (2-tailed) & & 0,002 & 0,001 \\
\hline & $\mathrm{N}$ & 45 & 45 & 45 \\
\hline $\begin{array}{l}\text { Implementasi SAK } \\
\text { ETAP }\end{array}$ & $\begin{array}{l}\text { Pearson } \\
\text { Correlation }\end{array}$ &, $444^{* *}$ & 1 &, $553^{* * *}$ \\
\hline & Sig. (2-tailed) & 0,002 & & 0,000 \\
\hline & $\mathrm{N}$ & 45 & 45 & 45 \\
\hline SOP Keuangan & $\begin{array}{l}\text { Pearson } \\
\text { Correlation }\end{array}$ &, $472^{* * *}$ &, $553^{* *}$ & 1 \\
\hline & Sig. (2-tailed) & 0,001 & 0,000 & \\
\hline & $\mathrm{N}$ & 45 & 45 & 45 \\
\hline **. Correlation is significant at the 0.01 level (2-tailed). & & \\
\hline
\end{tabular}

Sumber : Hasil Pengolahan SPSS versi 26

Berdasarkan Tabel 9. yang menjelaskan tentang korelasi atau besarnya hubungan antara variabel independen yaitu Implemenasi SAK ETAP dan SOP Keuangan terhadap variabel dependen yaitu Mutu Laporan Keuangan. Dari tabel output diperoleh nilai $\mathrm{R}=0,444$ artinya hubungannya sedang dan nilai Sig. (2tailed) antara Implementasi SAK ETAP (X1) dengan Mutu Laporan Keuangan (Y) sebesar 0,002 <0,05 yang berarti terdapat korelasi yang signifikan antara variabel implementasi SAK ETAP dengan variabel Mutu Laporan Keuangan. Hubungan antara SOP Keuangan (X2) dengan Mutu Laporan Keuangan (Y) sebesar $\mathrm{R}=0,472$ mempunyai hubungan sedang dan nilai Sig $0,001<0,05$ yang berarti terdapat korelasi yang signifikan antara variabel SOP Keuangan dengan variabel Mutu Laporan Keuangan.

b. Uji Koefisien Determinasi $\left(\mathbf{R}^{2}\right)$

Uji koefisien determinasi pada intinya mengukur seberapa jauh kemampuan variabel independen dalam menerangkan variabel dependennya. Nilai koefisien determinasi dapat dilihat pada Tabel 10

Tabel 10.

Hasil Uji Koefisien Determinasi

\begin{tabular}{ccccc}
\hline Model & R & R Square & $\begin{array}{l}\text { Adjusted R } \\
\text { Square }\end{array}$ & $\begin{array}{l}\text { Std. } \\
\text { Error of the } \\
\text { Estimate }\end{array}$ \\
\hline 1 & $\mathbf{, 5 2 1}^{\mathbf{a}}$ & $\mathbf{0 , 2 7 1}$ & $\mathbf{0 , 2 3 6}$ & $\mathbf{3 , 6 6 6}$ \\
\hline
\end{tabular}

a. Predictors : (Constant), SOP Keuangan, Implementasi SAK ETAP

b. Dependent Variable : Mutu Laporan Keuangan

Sumber : Hasil Pengolahan SPSS versi 26

Berdasarkan Tabel 10 dapat diketahui bahwa nilai dari koefisien determinasi adjusted $\mathrm{R}$ square yaitu sebesar 0,236. Hal ini berarti 23,6\% variasi dari mutu laporan keuangan dapat dijelaskan oleh variasi dari variabel independen yaitu implementasi SAK ETAP dan SOP Keuangan. Sedangkan sisanya $76,4 \%$ merupakan variasi variabel bebas lainnya yang tidak diteliti dalam penelitian ini. 


\section{c. Analisis Regresi Liner Berganda}

Uji analisis regresi linier berganda digunakan untuk mengetahui pola perubahan nilai varibel mutu laporan keuangan yang disebabkan oleh variabel implementasi SAK ETAP dan SOP Keuangan diperlukan alat analisis yang memungkinan kita untuk membuat perkiraan atau peramaian nilai variabel tersebut pada nilai tertentu variabel yang mempengaruhinya. Dalam penelitian yaitu analisis regresi. Pada penelitian ini menggunakan analisis regresi linear berganda.

Hasil analisis linear berganda dalam penelitian ini terlihat seperti Tabel 11:

Tabel 11.

Hasil Uji Analisis Regresi Linier Berganda

Coefficients $^{\mathrm{a}}$

\begin{tabular}{llccccc}
\hline \multirow{2}{*}{ Model } & \multicolumn{2}{c}{$\begin{array}{l}\text { Unstandardized } \\
\text { Coefficients }\end{array}$} & \multicolumn{2}{c}{$\begin{array}{c}\text { Standardized } \\
\text { Coefficients }\end{array}$} & & \multirow{2}{*}{ S } \\
\cline { 2 - 5 } & $\mathrm{B}$ & $\begin{array}{c}\text { Std. } \\
\text { Error }\end{array}$ & Beta & & \\
\hline 1 & 21,581 & 5,132 & & 4,205 & 0,000 \\
\cline { 2 - 5 } (Constant) & 0,217 & 0,130 & 0,264 & 1,669 & 0,103 \\
\hline $\begin{array}{l}\text { Implementasi } \\
\text { SAK ETAP }\end{array}$ & 0,269 & 0,130 & 0,326 & 2,061 & 0,045 \\
\hline
\end{tabular}

a. Dependent Variable: Mutu Laporan Keuangan

Sumber : Hasil Pengolahan SPSS versi 26

Dari Tabel 11 dapat diperoleh hasil regresi linier berganda sebagai berikut :

$\mathrm{Y}=\alpha+\beta_{1} \mathrm{X}_{1+} \beta_{2} \mathrm{X}_{2+\ldots} \mathrm{e}$

$\mathrm{Y}=21,581+0,217 \mathrm{X}_{1}+0,269 \mathrm{X}_{2}+\ldots \ldots . \mathrm{e}$

Jadi berdasarkan persamaan regresi linier berganda dapat diketahui sebagai berikut :

a. Konstanta ( $\alpha$ ) adalah 21,581 artinya jika implementasi SAK ETAP dan SOP Keuangan nilainya 0 maka mutu laporan keuangan nilainya 21,581

b. Nilai koefisien regresi variabel implementasi SAK ETAP (X1) bersifat positif yaitu 0,217 artinya jika implementasi SAK ETAP naik sebesar satu satuan maka nilai Mutu Laporan Keuangan akan bertambah sebesar 0,217 dengan syarat variabel SOP Keuangan (X2) bernilai 0. Nilai koefisien regresi variabel SOP Keuangan (X2) sebesar 0.269 artinya jika SOP Keuangan naik sebesar satu satuan maka Mutu Laporan Keuangan akan bertambah sebesar 0,269 dengan syarat variabel Implementasi SAK ETAP (X1) bernilai 0 .

\section{Uji Hipotesis}

a. Uji t

Uji hipotesis dilakukan untuk mengetahui ada tidaknya hubungan variabel independent terhadap variabel dependent. Suatu hasil uji hipotesis adalah suatu kriteria yang bisa menyebutkan satu persatu hasil dari sampel yang biasa menentukan diterima atau ditolaknya suatu hipotesis yang akan diuji atau pada umumnya disebut no hipotesisn dengan simbol $\mathrm{H}_{0}$. Hasil pengujian hipotesis dapat dilihat pada Tabel 12 . 
Tabel 12.

Hasil Uji Hipotesis (Uji t)

\begin{tabular}{lllllll}
\hline \multicolumn{6}{c}{ ANOVA $^{\text {a }}$} \\
\hline \multirow{2}{*}{ Model } & $\begin{array}{l}\text { Sum of } \\
\text { Squares }\end{array}$ & df & Mean Square & F & \multirow{2}{*}{ Sig. } \\
\hline \multirow{2}{*}{1} & Regression & 209,987 & 2 & 104,993 & 7,814 &, $001^{\text {b }}$ \\
\cline { 2 - 7 } & Residual & 564,324 & 42 & 13,436 & & \\
\cline { 2 - 7 } & Total & 774,311 & 44 & & & \\
\hline \multirow{2}{*}{ a. } & Dependent Variable: Mutu Laporan Keuangan & & \\
\hline b. & Predictors: (Constant), SOP Keuangan , Implementasi SAK ETAP & \\
\hline
\end{tabular}

Sumber : Hasil Pengolahan SPSS versi 26

Hubungan dari variabel implementasi SAK ETAP dan SOP Keuangan terhadap mutu laporan keuangan dapat dilihat dari arah tanda dan tingkat signifikasi (pribabilitas). Uji t dilakukan dengan cara membandingkan tingkat signifikasi < 0,05 . Hasil pengujian hipotesis yang dilakukan nilai koefisien parsial dari variabel independen terhadap dependennya sebagai mana terlihat pada Tabel 12. Variabel implementasi SAK ETAP dengan $t_{\text {hitung }} 1,669<t_{\text {tabel }} 2,01669$ maka dapat dikatakan bahwa variabel bebas terbukti tidak berhubungan dengan mutu laporan keuangan. SOP Keuangan dengan $t_{\text {hitung }} 2,061>t_{\text {tabel }}$ 2,01669 maka dapat dikatakan bahwa variabel SOP Keuangan terbukti terdapat hubungan antara SOP Keuangan dengan Mutu Laporan Keuangan.

b. Uji F

Menurut Imam Ghozali (2009) Uji statistik F pada dasarnya menunjukkan apakah semua variabel indenpenden yang dimasukkan dalam model mempunyai pengaruh secara bersama-sama atau simultan terhadap variabel dependen (Ghozali, 2009). Secara simultan pengaruh dari implementasi SAK ETAP dan SOP Keuangan terhadap mutu laporan keuangan ditunjukkan pada tabel berikut:

Tabel 13.

Hasil Uji Hipotesis (Uji F)

\begin{tabular}{|c|c|c|c|c|c|c|}
\hline \multicolumn{7}{|c|}{ ANOVA $^{\mathrm{a}}$} \\
\hline Model & & $\begin{array}{l}\text { Sum of } \\
\text { Squares }\end{array}$ & $\mathrm{df}$ & Mean Square & $\mathrm{F}$ & Sig. \\
\hline \multirow{3}{*}{1} & Regression & 209,987 & 2 & 104,993 & 7,814 &, $001^{\mathrm{b}}$ \\
\hline & Residual & 564,324 & 42 & 13,436 & & \\
\hline & Total & 774,311 & 44 & & & \\
\hline
\end{tabular}

a. Dependent Variable: Mutu Laporan Keuangan

b. Predictors: (Constant), SOP Keuangan , Implementasi SAK ETAP

Sumber : Hasil Pengolahan SPSS versi 26

Berdasarkan nilai $\mathrm{F}_{\text {hitung }}$ dan $\mathrm{F}_{\text {tabel }}$ :

1. Jika nilai $F_{\text {hitung }}>F_{\text {tabel }}$ dan Sig $<0,05$ maka variabel bebas $(\mathrm{X})$ berpengaruh terhadap variabel terikat $(\mathrm{Y})$.

2. Jika nilai $\mathrm{F}_{\text {hitung }}<\mathrm{F}_{\text {tabel }}$ dan $\mathrm{Sig}>0,05$ maka variabel bebas $(\mathrm{X})$ tidak berpengaruh terhadap variabel terikat $(\mathrm{Y})$.

Maka berdasarkan Tabel 13 diatas dapat dilihat dimana $F_{\text {hitung }}>F_{\text {tabel }}$ yaitu $7,814>4,07$ dengan tingkat signifikan dibawah 0,05 yaitu 0,001 . Berdasarkan cara pengambilan keputusan uji simultan dapat diartikan bahwa variabel implementasi SAK ETAP dan SOP Keuangan berpengaruh signifikan terhadap mutu laporan keuangan. 


\section{Pembahasan}

\section{Hasil Uji Metode}

\section{a. Koefisien Korelasi}

Berdasarkan perhitungan uji korelasi atau uji hubungan yang telah dilakukan, korelasi atau besarnya hubungan antara variabel independen yaitu implementasi SAK ETAP dan SOP Keuangan terhadap variabel dependen yaitu Mutu Laporan Keuangan. Hubungan korelasi antara implementasi SAK ETAP terhadap Mutu Laporan Keuangan diperoleh nilai $\mathrm{R}=0,444$ artinya hubungannya sedang dan nilai Sig. (2-tailed) antara Implementasi SAK ETAP (X1) dengan Mutu Laporan Keuangan (Y) sebesar 0,002 <0,05 yang berarti terdapat korelasi yang signifikan antara variabel implementasi SAK ETAP dengan variabel Mutu Laporan Keuangan. Hubungan antara SOP Keuangan (X2) dengan Mutu Laporan Keuangan (Y) sebesar $\mathrm{R}=0,472$ mempunyai hubungan sedang dan nilai Sig $0,001<0,05$ yang berarti terdapat korelasi yang signifikan antara variabel SOP Keuangan dengan variabel Mutu Laporan Keuangan.

\section{b. Koefisien Determinasi}

Berdasarkan perhitungan uji determinasi atau uji pengaruh yang telah dilakukan, maka diperoleh hasil koefisien determinasi adjusted $\mathrm{R}$ square yaitu sebesar 0,236. Hal ini berarti 23,6\% variabel Implementasi SAK ETAP dan SOP Keuangan mempengaruhi mutu laporan keuangan. Sedangkan sisanya 76,4\% merupakan variasi variabel bebas lainnya yang tidak diteliti dalam penelitian ini.

\section{c. Koefisien Regresi Linear Berganda}

Persamaan regresi linear berganda hasilnya $\mathrm{Y}=21,581+0,217 \mathrm{X}_{1}+0,269 \mathrm{X}_{2}$ + ...e. Jadi berdasarkan persamaan regresi linier berganda tersebut dapat dijelaskan sebagai berikut :

1. Konstanta ( $\alpha$ ) adalah 21,581 artinya jika implementasi SAK ETAP dan SOP Keuangan nilainya 0 maka mutu laporan keuangan nilainya 21,581.

2. Nilai koefisien regresi variabel implementasi SAK ETAP (X1) bersifat positif yaitu 0,217 artinya jika implementasi SAK ETAP naik sebesar satu satuan maka nilai Mutu Laporan Keuangan akan bertambah sebesar 0,217 dengan syarat variabel SOP Keuangan (X2) bernilai 0. Nilai koefisien regresi variabel SOP Keuangan (X2) sebesar 0,269 artinya jika SOP Keuangan naik sebesar satu satuan maka Mutu Laporan Keuangan akan bertambah sebesar 0,269 dengan syarat variabel Implementasi SAK ETAP (X1) bernilai 0.

\section{Hasil Uji Hipotesis}

a. Uji T

Hubungan dari variabel implementasi SAK ETAP dan SOP Keuangan terhadap mutu laporan keuangan dapat dilihat dari arah tanda dan tingkat signifikasi (pribabilitas). Uji t dilakukan dengan cara membandingkan tingkat signifikasi < 0,05. Hasil pengujian hipotesis yang dilakukan nilai koefisien parsial dari variabel independen terhadap dependennya sebagai mana terlihat pada Tabel 4.12.

Variabel implementasi SAK ETAP diperoleh $\mathrm{t}_{\text {hitung }} 1,669<\mathrm{t}_{\text {tabel }} 2,01669$ dan signifikansi 0,103 >0,05 maka dapat dikatakan bahwa variabel bebas terbukti tidak berhubungan dengan mutu laporan keuangan. SOP Keuangan dengan $t_{\text {hitung }}=2,061>$ $\mathrm{t}_{\text {tabel }}$ 2,01669 dan signifikansi 0,045 $<0,05$ maka dapat dikatakan bahwa variabel SOP Keuangan terbukti terdapat hubungan antara SOP Keuangan dengan Mutu Laporan Keuangan.

b. Uji F

Berdasarkan Tabel 13 dapat dilihat dimana $F_{\text {hitung }}>F_{\text {tabel }}$ yaitu 7,814 $>4,07$ dengan tingkat signifikan dibawah 0,05 yaitu 0,001 . 
Berdasarkan cara pengambilan keputusan uji simultan dapat diartikan bahwa variabel implementasi SAK ETAP dan SOP Keuangan berpengaruh signifikan terhadap mutu laporan keuangan.

\section{KESIMPULAN}

Berdasarkan tujuan penelitian maka disimpulkan:

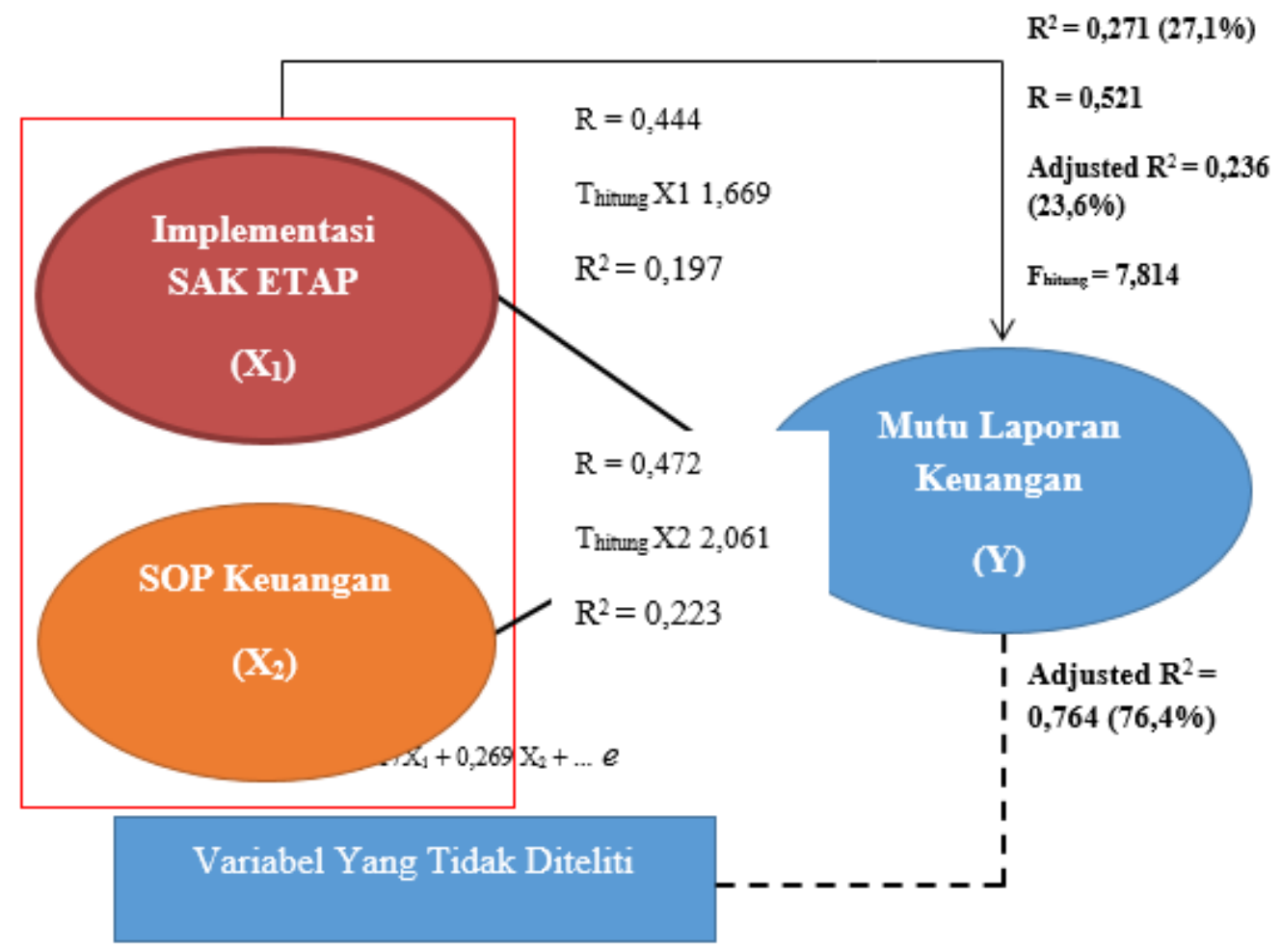

Sumber : Diolah, 2020

\section{Gambar 1. \\ Hasil Model Penelitian}

\section{Hasil Uji Pengaruh}

a. Berdasarkan Tabel 4.10 Koefisien Determinasi $\left(\mathrm{R}^{2}\right)$ menunjukkan $23,6 \%$ artinya mutu laporan keuangan dipengaruhi variabel independen yaitu implementasi SAK ETAP dan SOP Keuangan, sedangkan sisanya 76,4\% dipengaruhi variabel lainnya yang tidak diteliti.

b. Berdasarkan Analisis Regresi Linier berganda diperoleh $\mathrm{Y}=21,581+0,217 \mathrm{X} 1+$ $0,269 \mathrm{X} 2+\ldots$ e konstanta sebesar 21,581 menyatakan bahwa implementasi SAK ETAP dan SOP Keuangan nilainya 0 maka mutu laporan keuangan nilainya 21,581.

c. Nilai koefisien regresi variabel implementasi SAK ETAP (X1) bersifat positif yaitu 0,217 artinya jika implementasi SAK ETAP naik sebesar satu satuan maka nilai Mutu Laporan Keuangan akan bertambah sebesar 0,217 dengan syarat variabel SOP Keuangan (X2) bernilai 0. Nilai koefisien regresi variabel SOP Keuangan (X2) sebesar 0,269 artinya jika SOP Keuangan naik sebesar satu satuan maka Mutu 
Laporan Keuangan akan bertambah sebesar 0,269 dengan syarat variabel Implementasi SAK ETAP (X1) bernilai 0 .

d. Berdasarkan hasil Uji $\mathrm{F}$ dapat dilihat dimana Fhitung > Ftabel yaitu 7,814 > 4,07 dengan tingkat signifikan dibawah 0,05 yaitu 0,001 . Berdasarkan cara pengambilan keputusan uji simultan dapat disimpulkan bahwa variabel implementasi SAK ETAP dan SOP Keuangan berpengaruh signifikan terhadap mutu laporan keuangan.

\section{Hasil Uji Hubungan}

a. Hasil analisis hubungan antara variabel independen yaitu implementasi SAK ETAP dan SOP Keuangan terhadap variabel dependen yaitu Mutu Laporan Keuangan. Dari Tabel 4.9 diperoleh nilai $\mathrm{R}=0,444$ artinya hubungannya sedang dan nilai Sig. (2tailed) antara Implementasi SAK ETAP (X1) dengan Mutu Laporan Keuangan (Y) sebesar $0,002<0,05$ yang berarti terdapat korelasi yang signifikan antara variabel implementasi SAK ETAP dengan variabel Mutu Laporan Keuangan. Hubungan antara SOP Keuangan (X2) dengan Mutu Laporan Keuangan (Y) sebesar R = 0,472 mempunyai hubungan sedang dan nilai Sig 0,001 $<0,05$ yang berarti terdapat korelasi yang signifikan antara variabel SOP Keuangan dengan variabel Mutu Laporan Keuangan.

b. Berdasarkan Uji $\mathrm{T}$ diperoleh Variabel implementasi SAK ETAP dengan thitung $(1,669)$ < ttabel $(2,01669)$ maka dapat dikatakan bahwa variabel bebas terbukti tidak berhubungan variabel terikat dengan mutu laporan keuangan. SOP Keuangan dengan thitung $(2,061)>$ tabel $(2,01669)$ maka dapat dikatakan bahwa variabel SOP Keuangan terbukti terdapat hubungan antara SOP Keuangan dengan Mutu Laporan Keuangan.

\section{Hasil Banding Studi Empiris}

Berdasarkan studi empiris sebelumnya penelitian ini pernah dilakukan oleh Roza Fitriawati, mahasiswi Universitas Bung Hatta Padang Jurusan Akuntansi dengan judul "Kualitas Laporan Keuangan Untuk Usaha Mikro Kecil Menengah (UMKM) dan Prospek Implementasi Standar Akuntansi Keuangan Entitas Tanpa Akuntabilitas Publik (SAK ETAP) (Studi Kasus pada UMKM di Sumatera Barat)".

Penelitian ini bertujuan untuk menunjukan pentingnya pembukuan dan pelaporan keuangan bagi usahanya. Selanjutnya pengaruh kualitas laporan keuangan UMKM terhadap besarnya jumlah kredit perbankan yang diterima oleh UMKM dan pengaruh pemberian informasi dan sosialisasi SAK ETAP, latar belakang pendidikan pengusaha, jenjang pendidikan terakhir pengusaha terhadap pemahaman pengusaha UMKM terkait SAK ETAP.

Data penelitian ini di ambil dengan menyebarkan kuesioner kepada UMKM. Sehingga menghasilkan 90 responden dari UMKM yang ada di Sumatera Barat.

Hasil penelitian menunjukan bahwa kualitas laporan keuangan berpengaruh terhadap semakin besarnya jumlah kredit perbankan yang diterima UMKM. Pemberian informasi dan sosialisasi SAK ETAP dan latar belakang pendidikan berpengaruh terhadap pemahaman pengusaha UMKM terkait SAK ETAP, jenjang pendidikan tidak berpengaruh terhadap pemahaman pengusaha UMKM terkait SAK ETAP

\section{BIBLIOGRAFI}

Alhusain, A. S. (2016). Kendala dan Upaya Pengembangan Industri Batik di Surakarta Menuju Standardisasi. Jurnal Ekonomi \& Kebijakan Publik, 6(2), 199-213.

Anggraeni, F. D. (2013). Pengembangan Usaha Mikro, Kecil dan Menengah (UMKM) Melalui Fasilitasi Pihak Eksternal dan Potensi Internal (Studi Kasus Pada 
Kelompok Usaha" Emping Jagung" di Kelurahan Pandanwangi Kecamatan Blimbing Kota Malang). Jurnal Administrasi Publik, 1(6), 1286-1295.

Ardhanariswari, K. A., Wijayani, A., \& Probosari, N. (2021). STRATEGI BRANDING MELALUI SOSIAL MEDIA DAN PERLINDUNGAN HKI PADA UMKM KOPI WONOGIRI. Prosiding Seminar Nasional LPPM.

Baas, T., \& Schrooten, M. (2006). Relationship banking and SMEs: A theoretical analysis. Small Business Economics, 27(2-3), 127-137.

Fatimah, F., \& Darna, D. (2011). Peranan Koperasi dalam Mendukung Permodalan Usaha Kecil dan Mikro (UKM). Jurnal Ekonomi \& Bisnis PNJ, 10(2), 13428.

Ghozali, I. (2009). Ekonometrika: teori, konsep dan aplikasi dengan SPSS 17. Semarang: Badan Penerbit Universitas Diponegoro, 50.

Hasan, K. (2013). CONTOH DALAM RANAH ILMU KOMUNIKASI (Membumikan Kualitas Penelitian).

Pujiyanti, N. (2018). Strategi Pengembangan Usaha Produk Kering Perikanan Dengan Menggunakan Model Maut (Multi Attribute Utility Theory) Pada Poklahsar "Sumber Sari" Di Desa Sidorejo, Kecamatan Pagelaran, Kabupaten Malang, Jawa Timur. Universitas Brawijaya.

Said, A. M. F. (2015). Strategi Pemberdayaan UMKM Pada Dinas Koperindag Kabupaten Maros (Studi Kasus Pada Sektor Perdagangan). Universitas Hasanudin, Makasar.

Sugiyono, P. (2011). Metodologi penelitian kuantitatif kualitatif dan R\&D. Alpabeta, Bandung.

Tuti, R. (2016). Faktor-faktor yang mempengaruhi pemahaman UMKM dalam menyusun laporan keuangan berdasarkan SAK ETAP. Jurnal Akuntansi Kontemporer, 8(2), 98-107.

UTAMI, S. K. (2014). Keputusan Pengadopsian Cloud Computing oleh Usaha Kecil Menengah (UKM) di Indonesia: Technological-Organizational-Environmental (TOE) Framework. [Yogyakarta]: Universitas Gadjah Mada. 